\title{
"Shine! Shine! O New Jerusalem!" - The Theme of Holy City in the Work of Old-Russian Composer Fyodor Krestjanin
}

\author{
Natalia Parfentieva \\ History Department \\ South Ural State University \\ Chelyabinsk, Russia \\ E-mail: parfentevanv@susu.ru
}

\author{
Nikolai Parfentiev \\ History Department \\ South Ural State University \\ Chelyabinsk, Russia \\ E-mail: parfentevnp@susu.ru
}

\begin{abstract}
The ideologemes of Moscow as the New Jerusalem and New Rome, first emerged during the eminence of Moscow as seat of the unified Russian State. Such ideology primarily was gaining its foothold in the political consciousness of Russian ruling elite in the $16^{\text {th }}$ and in the early $17^{\text {th }}$ centuries. A variety of scientific research identify the ideology in various arts of iconography, architecture, literature, church and liturgical theatrical performance, yet, the manifestation of the theme of Moscow representing the 'Holy City' in the OldRussian music has been under study for the first time ever. The contributors are analyzing the particular hymn "Shine! Shine! O New Jerusalem!" in the version of Moscow raspevshik (composer) Fyodor Krestjanin, composed on the surge of interest in this ideological idea. Krestjanin had created own hymnographic chant on the model of the Demestvenny polyphony, addressed to the image of New Jerusalem. The authors review the creation based on the unique record made by one of the tsar's chorister dating back to 1600, which evidences of the enormous interest in the mastering of Fyodor Krestjanin's chant among the tsar's "singing dyaks" (choristers). The article invites to study the authors' concept of the "Holy City" theme development by Fyodor Krestjanin in musical form.
\end{abstract}

Keywords-old Russian chanting art; authorship; Fyodor Krestjanin

\section{INTRODUCTION}

Interest of the historical scientific research to the concepts of Moscow being New Jerusalem and, especially, the third Rome does not fall ${ }^{1}$. The key historical factors of such concepts' evolution became the fall of Constantinople (1453), overthrow of the Mongol-Tatar Yoke in Russia (1480) and the unification of Russian lands under Moscow's guidance. The Grand Duke of Moscow proved to be the only sovereign ruler in the Orthodox Christian world. Orthodox Christians of Muscovia depicted Byzantium in two symbolic forms - as Constantinople the New Jerusalem, the Heavenly theocratic city, and, at the same time, as New Rome the Imperial Capital of the World. Moscow had to assume the

${ }^{1}$ Detailed review of the studies is presented, for instance, in the work of A.S. Usachev [35]. status of the Byzantine Empire since its fall. In such circumstances the political and religious aspects of the "Moscow as the Third Rome" and "Moscow as New Jerusalem" doctrines had fused into general theocratic context.

Translation of the idea of "Moscow as New Jerusalem" in art works has an extensive historiography. A considerable amount of studies in this vein has been dedicated to the grand artwork of the middle of the 16th century from the Assumption Cathedral of the Moscow Kremlin -the icon "Blessed Be the Host of the Heavenly Tsar". The icon shows movement of warriors led by the Archangel Michael and Ivan IV the Terrible away from a burning city (probably it is Kazan) toward a tent-topped Heavenly City upon a mountain (New Jerusalem) - toward Moscow ${ }^{2}$. This theme can ben read on the icon of The Last Judgment from the National Museum of Sweden [13]. Here should be mentioned the works on mural paintings of the Golden Tsarina's Chamber (1547-1553) and the Archangel Cathedral (1564-1565) in the Kremlin, the Cathedral of the Intercession of the Most Holy Theotokos on the Moat (1554-1560), the bas-reliefs of the ambo of Ivan the Terrible in in the Kremlin's Assumption Cathedral (1551), the miniature paintings of the Illustrated Chronicle (Litsevoj litopisnyi svod, the second half of the $16^{\text {th }}$ century), and on liturgical theatrical action called "The Procession Sitting on an Ass's Colt" [6] [17] [32] [2] [7] [34] [1] [8]. As can be seen, the reflection of the "Moscow the New Jerusalem" ideologeme in the cultural and art monuments has long been in the center of scholars' attention. Yet, the problem of its expression in the art of liturgical singing has been dramatically under-examined.

The idea of Moscow, the third Rome in Old-Russian chanting has been analysed for the first time by contemporary Russian researcher N.V. Ramazanova, who points to the Old-Russian liturgical book Sticherarion with a set of chants honouring Roman Saints, which, in turn, alludes to the Moscow Tsardom's succession to Roman Kingdom

\footnotetext{
${ }^{2}$ This has been addressed by M. K. Karger, O. I. Podobedova, V. V. Morozov, I. A. Kochetkov, N. V. Kvlividze, V. M. Sorokaty, A. B. Konotop, S. N. Bogatyrev, M. Perrie and other researchers.
} 
[18]. The interpretation by musical art of the "Moscow, New Jerusalem" ideologeme has not been previously studied and is presented in this work for the first time. Its authors proceed to consider the implementation of the idea using the example of certain chants, starting with the Paschal hymn (Zadostoinik) 'Shine! Shine! O New Jerusalem!'

\section{Musical DeVElopMENT OF THE "ShINE! SHINE! O NEW JERUSALEM!” HYMN}

The phrase "New Jerusalem" originates from the Apocalypse (Rev. 3, 12; 21, 2) and directly refers to the Paschal hymn "Shine! Shine! O New Jerusalem!" which is the irmos of the ninth Ode (the first tune) of the Paschal Canon, composed by the outstanding Byzantine theologian and hymnographer St. John Damascus (VIII) and dedicated to the Resurrection of Christ, leading Christians from death to eternal life, from the Earthly to the Heavenly. In this irmos, the Reverend John, explaining the event, is comparing Jerusalem's Holy Land, or Zion, with its heavenly prototype New Jerusalem:

\section{Shine! Shine! O New Jerusalem!}

The Glory of the Lord has shone on you!

\section{Exalt now and be glad, O Zion!}

Be radiant, $O$ Pure Theotokos, in the Resurrection of your Son!

The hymnographic text is of ancient origin. The first music versions of the text in Russian were found not earlier than the first half of the $16^{\text {th }}$ century. It was at that time the idea of Moscow as New Jerusalem was crystalizing into a concept. Later times witnessed musical flourishing of the piece.

Through the second half of the $16^{\text {th }}$ and in the $17^{\text {th }}$ centuries, the hymnographic text of "Shine! Shine! O New Jerusalem!" received many vocal versions of various styles and notations. All of the versions were composed as the Paschal hymn (instead of the chant to the Holy Mother of God "It Is Truly Meet"). What was the impetus to this creative surge in composing new chants to the hymnographic text, including original one? The first thing to stress is that the hymn was executed just once a year during the Easter service. Creating more and more original chants, their authors, presumably, sought to convey special spiritual and religious attitude toward the most important central celebration.

The phenomenon whereby one and the same hymnographic text gets several melodic variations is widely represented in the choral manuscript and its widespread acceptance is evidenced by narrative sources. For instance, Login Shishelov, the eminent precentor of the TrinitySergius monastery's choir, had taught his nephew Maxim to sing one and the same text in ten melodies, and himself could execute chants in 17 variations [15]. Accordingly, such multi-melody phenomenon was not uncommon.

Even in view of this, however, the musical variations of the "Shine! Shine! O New Jerusalem!" hymn, found by the authors in manuscripts, constitute a unique phenomenon. The authors are attributing this to the fact that the ancient hymnographic text in new historical context had been explicitly relatable to the idea of "Moscow as New Jerusalem". New compound projection was dawning: Old Jerusalem (Zion) - New Jerusalem (Heavenly City) Moscow (New Jerusalem). Moscow took over the holiness of Zion's sacred places and the spiritual light of Heavenly Jerusalem with its eschatological destiny [17].

Here are a few of musical variations of the hymn "Shine! Shine! O New Jerusalem!" that were discovered in manuscripts of the last quarter of the 16th and 17th centuries:

1) The most popular syllabic znamenny chant (over 30 copies) in the first tone [3] [9] [21] [22];

2) Another version of the syllabic znamenny chant) in the first tone [10] [23] [25] [29];

3) A recitative znamenny-like version [26];

4) The Usolsky (Stroganov) syllabic version [5];

5) The melismatic-style "monastery" chant (probably, Demestvenny) as presented by "Stolp" (Stolpovoy, close to Znamenny) neumatic notation [22] [24] [30];

6) Versions of Putevoy style: $a$ ) the syllabic type of Putevoy neumatic notation [11] [20]; $b$ ) the melismatic type of Putevoy neumatic notation [27]; $c$ ) the version in the Stolp neumatic notation [4];

7) Versions of Demestvenny style: $a$ ) the syllabic type of the Demestvenny notation [20] [26]; $b$ ) the Stolp notation [25] [28]; c) the 'Great' chant in the Stolp notation [25].

Among this amazing abundance of versions, including the new Great chants of different musical styles, we have selected one the most interesting for our research as it has an exact date (1600) and belongs to work of the distinguished court chanting master Fyodor Krestjanin (†1607) [19].

\section{FYODOR KRESTJANIN'S MUSICAL VARIATION OF THE HYMN IN THE COURT CHOIR REPERTOIRE}

It is important to point out that during the reign of Ivan the Terrible he had gathered around him the best masters of the church-chanting art. The sources lead to the conclusion that the development of Moscow school as a unique creative trend of the Old-Russian music took place in that period. Master Fyodor Krestjanin was destined to play the decisive role at this stage. His chants for music theorists of the late $16^{\text {th }}$ and in the $17^{\text {th }}$ centuries become the embodiment of "Moscow chanting".

Manuscripts from the library of the Tsar's singing dyaks (choristers) prove that Moscow masters were paying a special honor particularly to the chants composed by Krestjanin, or "Khristianin" (the Christian). He began his service at the court of Ivan IV in the Aleksandrovskaya Sloboda and after the court moved to Moscow Krestjanin started his service as a priest of the court Annunciation Cathedral in the Kremlin. He patronized the best Russian masters of the chanting art, choristers of the tsar's choir 
(singing dyaks and podyaks). Krestjanin, who served under five sovereigns, had won great authority as 'raspevschik' (chanting master) and didascalos among choristers who considered him as their teacher and 'master'[14]. Firstly, Krestjanin was responsible for teaching of young dyaks of the Tsar's choir. He helped the court choristers master musical instructions (razvody) of complex neumatic notation symbols, formulas and 'taynozamknenny' (encrypted) chant lines. For this purpose the singing dyaks under the master's care wrote special notebooks, the so-called 'stolptsy rozvodnye' (handwritten razvody).

A lively atmosphere of Krestjanin's lessons in 'singing chambers' was captured in the notes of some Anonymous Dyak of the tsar's choir. The latter mentions that in view of coming Easter Krestjanin had sung to his students the Paschal hymn "Shine! Shine! O New Jerusalem!" in Demestvenny chant, which the Dyak recorded in neumatic notation. The handwritten copies close to this chant variant are rare and belong to a later period. We have just two records, which are similar to the master's. Both are dated the first half of the 17th century and present the Stolp neumatic notation and are annotated 'Demestvo'.

Dyak notes, "My neumes, the master sang, of the year 7108 [1600] March 21st. During the Holy Easter Week, in place of "It Is Truly Meet", Demestvo" [19].

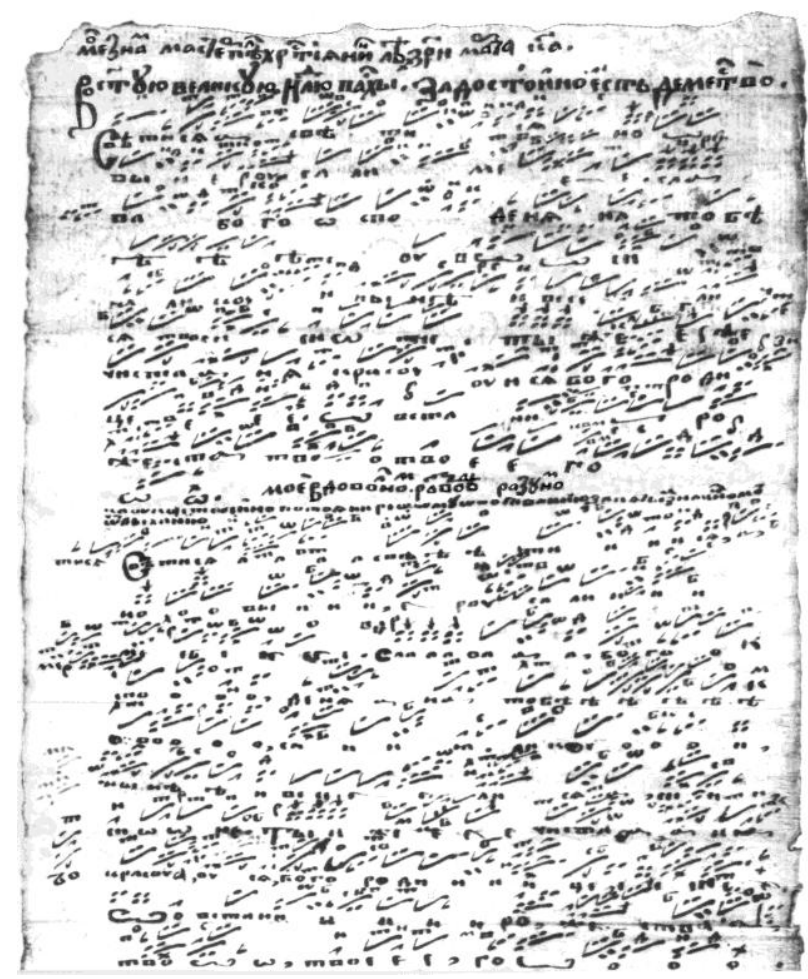

Fig. 1. "My neumes. Sang Master Khristiyanin." Easter Hymn "Shine!" Demestvenny chant, March 21, 1600. (RGADA, F. 188. Op. 1. No. 1585.L.1)

The situation that emerges is, while getting ready for the Easter holiday, Fyodor Krestjanin together with the Anonymous Dyak (presumably acting as precentor) were finalizing melody of the hymn "Shine! Shine! O New
Jerusalem!" They chose for execution a complicated melismatic demestvenny chant. Cross-referencing the earlier recorded variation (№1) and new one (№2) of Krestjanin’s chant, the Dyak formed yet another, "corrected", variation (№3) ought to be rendered with the choristers "on the master's recommendation".
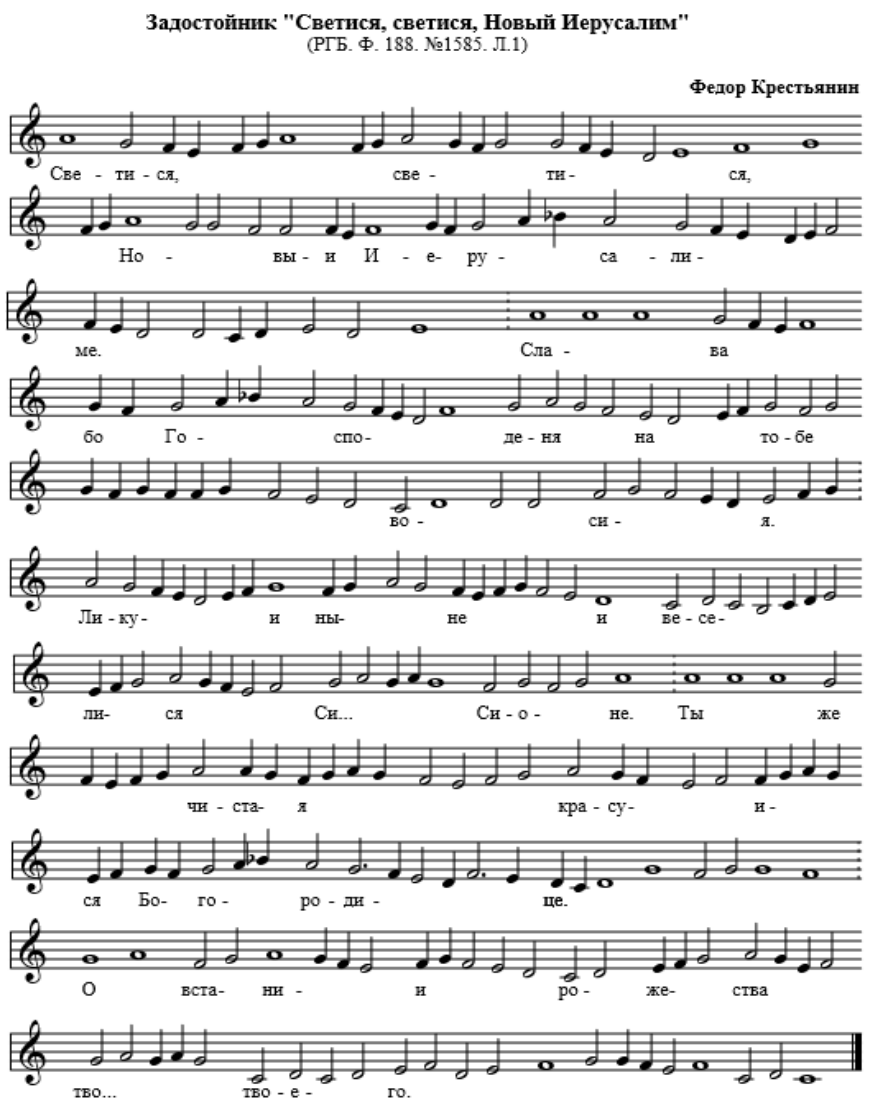

Fig. 2. The Hymn “Shine! Shine! O new Jerusalem!", Fyodor Krestjanin (RGB. F. 188. No. 1585.L.1)

It should be pointed out that in 1600 , in the reign of Boris Godunov, Krestjanin's hymn "Shine!" underwent careful theoretical and interpretative analysis. The proponent of the idea of "Moscow, New Jerusalem", Godunov initiated the construction in the Kremlin of the New Jerusalem Cathedral. Moscow full of cathedrals and monasteries had been perceived as the scene of special, mysterious presence of the Heavenly Tsar of Glory - Lord Jesus Christ, His Most Blessed Mother, the hosts of heaven and the triumph Church of Saints. Otherwise speaking, Moscow was perceived as the representation of Heavenly Jerusalem. Rendering Krestjanin's new Demestvenny chant at the great Easter holiday, the tsar's choristers were concurrently praising the Russian land as embodiment of the Holy Land (Zion) and as the representation of coming Heavenly Kingdom. What are the musical means helping unveil these images in the hymn? 


\section{KRESTJANIN'S MusicAl MEANS EXPANDING THE SEMANTIC SCOPE OF THE HYMN}

Before Fyodor Krestjanin, the text of this chant was sung short in a syllabic style, when one syllable had just one neume. For instance, the syllabic chant in the manuscript of the year 1584 consists of sixty-one neumes [9]. Krestjanin created new melismatic chant in the Demestvo style, dramatically expanding its musical structure to 160 neumes. A short poetic text was given the form conforming to its momentous semantic meaning in liturgy. However, the intrasyllabic melodies aren't hypertrophied and extend from two to twelve sounds per syllable in the master's variation. Probably, an over-developed musical line was deemed to be inappropriate since this could eclipse the message of the text, which, in a condensed form, presents the idea of "the Holy City".

The hymn has the Stolp notation (Stolpovoy). Yet it differs from general Stolp notation by unusual combination of neumes and their complex marking ${ }^{3}$. The graphics of certain neumes have rare for notation of that time direction of the maximum pitch. In this respect deserves attention the sequence of three longest and highest identical neumes (called "statja svetlaya s sorochjey nozhkoy" - the long stop of the utmost height on the pitch). They are placed over the words "Glory" and "Thou". Such sequence is unrepresentative of the general Stolpovoy chanting. The technique is called "capture by Demestvo", whereby a new line starts with the highest sound (these are the words that open the second and the fourth lines). Applying this technique the author added culmination to the beginning of the lines. The musical accentuation of the word "Glory", and therefore of the entire phrase "Glory of the Lord" is natural. The utmost glorifying was shown. The same is the musical emphasis of the word "Thou" that opens the phrase addressed to the Mother of God "Thou, be radiant, O Pure Theotokos". This technique appears one more time in the beginning of the final line "In the Resurrection of your Son". Thus, the author outlines the semantically key collocations of the hymn 'For the Glory of the Lord', 'Thou, Pure Theotokos' and 'In the Resurrection' by the unified musical technique "Table I, technique B". The musical content flexibly follows the semantics of the verbal text. The musical techniques accentuate the climax zones, keywords and the start of lines and fragments.

In what manner does the music translate the "Holy City" message? The poetic text of the hymn falls into three parts. The first one presents the appeal to the New Jerusalem (Lines 1-2), the second - to Zion (Line 3) and the third - to the Theotokos (Lines 4-5). The first part consists of two lines chanted in 55 and 52 sounds respectively. The longest chanting falls on the keyword Jerusalem (23 sounds). Its sophisticated melodic line is melodically accentuating the special signification of the word. By analogy with the first line, the third one, from which the second part begins, presents this time the appeal to old Jerusalem - to Zion.

\footnotetext{
${ }^{3}$ Two notations were used for writing demestvenny chants: the special demestvenny or, as in our case, more common Stolp notation.
}

\section{The first line: Shine! Shine! O New Jerusalem!}

\section{The third line: Rejoice and exult now, O Zion!}

The musical content of the chanted word Zion has only ten sounds and significantly falls behind by the the length and complexity of the sung word Jerusalem. The two cities Heavenly and Earthy - counter each other, the Heavenly City is presented in music as superior, and predominant (the first part chanting includes 101 sounds). Meanwhile, Zion occupies a subordinate position in the hierarchy (the second part has just 43 sounds). The author stresses their difference rather than their unity; yet the unity of these cities is also musically expressed. By this is meant the acclamations Shine in the first line as referred to Jerusalem, and Rejoice in the third line - to Zion, which have nearly identical chanting. The musical unity of the initial intonation of these words emphasizes the semantic parallelism of New Jerusalem and Zion's similarity "Table I, B".

TABLE I. REFLECTION OF SEMANTIC CONTENT OF THE HyMN TEXT By Musical MEANS

\begin{tabular}{|c|c|c|c|}
\hline No & Verbal text of the line & $\begin{array}{c}\text { Musical } \\
\text { techniques } *\end{array}$ & $\begin{array}{l}\text { Num-ber } \\
\text { of sounds } \\
\text { in the line }\end{array}$ \\
\hline 1 & $\begin{array}{l}\text { Светися, светися Новый } \\
\text { Иерусалиме } \\
\text { Shine! Shine! O New Jerusalem }\end{array}$ & $\mathrm{AC}$ & 51 \\
\hline 2 & $\begin{array}{l}\text { Слава бо господня на тобе восия. } \\
\text { For the glory of the Lord hath risen } \\
\text { upon thee. }\end{array}$ & B & 50 \\
\hline 3 & $\begin{array}{l}\text { Ликуй ныне и веселися, Сионе! } \\
\text { Rejoice and exult now, O Zion! }\end{array}$ & A & 43 \\
\hline 4 & $\begin{array}{l}\text { Ты же Чистая красуйся, } \\
\text { Богородице, } \\
\text { Thou, pure Theotokos, be radiant }\end{array}$ & B C & 50 \\
\hline 5 & $\begin{array}{l}\text { О восстании рождества твоего. } \\
\text { In the Resurrection of thy Son. }\end{array}$ & B1 & 44 \\
\hline
\end{tabular}

Further, in the fourth line (beginning of the final third part) the word Theotokos is highlighted by the long melismatic chanting close to the singing of the word Jerusalem, which emphasises the semantic unity of these representations. In the musical context the third part (invocation of the Theotokos) is connected with the first one (close chanting of Jerusalem' and Theotokos, capture by Demestvo at the beginning of the second, fourth and fifth lines). These musical techniques are accentuating the closeness of the representations of New Jerusalem and the Mother of God.

\section{CONCLUSION}

In summary, by applying musical means the composer managed to demonstrate in the hymn the unity of and distinction between the two worlds - New Jerusalem and Zion. The representation of Jerusalem is conveyed by a more 
prolonged and sophisticated development of the melodic lines. The music with intonation rising to extremely high sounds and with high range of sound reflects the image of the Holy City as though floating in the air. The representation of Zion is musically inferior. Its presentation is more modest and depicted just in a single line. The key words-symbols are denoted in music with the help of either "the capture by Demestvo" or the reiteration of the melodic content (words Jerusalem and Theotokos). The resemblance of New Jerusalem to Zion is presented only as an allusion. The Mother of God is in the center of the hymnody as the brightest star of the Holy Land, as epitome of the highest holiness. This musical concept is consistent with the idea of Moscow as New Jerusalem. In honor of the Mother of God as Russia's patroness and protectrix, the Assumption Cathedral in the Moscow Kremlin was built to become the central Cathedral of Muscovia. The Vladimir icon of the Mother of God became Russia's major sanctity. The deep reverence for New Jerusalem and the Mother of God in explicitly perceived in Fyodor Krestjanin's conception as well.

In general, the hymn reflects the features of demestvenny style, the most solemn in the music of that period. Of course, Fyodor Krestjanin had not been the author of this style, which, according to sources, appeared in the last quarter of the $15^{\text {th }}$ century. Nevertheless, he certainly accepted and perfectly mastered it since he was a disciple of the Novgorod master Savva Rogov, whose brother and disciple Varlaam Rogov was the famous raspevshik (composer) of demestvenny chanting [31]. Fyodor Krestjanin's hymn was executed within the canon of Demestvo. The chant retains such style features as typical demestvenny formulas and variation type of their melodic development. The hymnody has a moderate melismatics and original rhythm that arises from the use of complex neumes (the so-called "strela" arrow). All of this gave a festive character to this demestvenny chant melody. It is no coincidence that in written sources of the time the demestvenny style of singing was often called "red", that is beautiful. The festivity, solemnity and scale of the composition placed Krestjanin's hymn on a par with prominent artworks.

Consequently, on the threshold of Easter on the $21^{\text {st }}$ of March, 1600 the court master Fyodor Krestjanin created and learned with the tsar's singing dyaks the new demestvenny chant of the hymn "Shine! Shine! O New Jerusalem!". The master being the archpriest of the Annunciation Cathedral, the family chapel of Russian tsars, had direct access to the Tsar (at that moment, Boris Godunov), who was a fervent supporter of the idea of Moscow being New Jerusalem. Probably he could not be satisfied with the old chanting tradition of the ancient text, directly related to the central idea of the era. In the new historical realities of the Russian State John Damascene's poetic text takes on a different nationwide messianic tone. Sensing the needs of the time, and possibly on the Tsar's direct orders, Fyodor Krestjanin creates a new musical variation of the hymn, a particular solemn style of Demestvo. The characteristics of the ideological and artistic worldview of Muscovy had been reflected in the master's chant. One can only imagine the force of impact of the famous master's new music performed by the best singers of the state, praising the Russian land as the Holy Land and the coming Heavenly Kingdom.

It can be seen that in the $16^{\text {th }}$ century the idea of Moscow as the new center of Orthodoxy - the Holy Jerusalem had been also reflected in the music art. The outstanding composer and singer Fyodor Krestjanin had realized this concept through the means of music art, actually creating in the context of new historical realities the new music composition for the ancient canonical text.

\section{REFERENCES}

[1] A. A. Amosov, "The Illustrated Chronicle of Ivan the Terrible", Moscow, 1998.

[2] F. L. Batalov, L. S. Uspenskaia, "Cathedral of the Intercession of the Most Holy Theotokos on the Moat (St. Basil's Cathedral)", Moscow, 2004.

[3] BRAN (Library of the Russian Academy of Sciences, St. Petersburg), Arkh. pev. 4.

[4] BRAN, Osn. 16.7.24.

[5] BRAN, Strog. 40.

[6] M. K. Flaier, "To semiotic analysis of the Golden Chamber of the Moscow Kremlin", Old Russian Art. Russian art of the late Middle Ages, the XVI century, St. Petersburg, 2003, pp. 178-187.

[7] M. K. Flaier, “Throne of Monomakh' of Ivan the Terrible”, in Iconostasis. Origin - development - symbolics, Moscow, 2000, pp. 599-620.

[8] M. K. Flier, "Code definition: the tsar's image in the Palm Sunday ceremony in the Moscow State", in J. Madzheska (ed.), American Russian philology: milestones of historiography of past years, Samara 2001, pp. 203-239.

[9] GIM (State Historical Museum, Moscow), Edinover. 37.

[10] GIM, Sin. slav. 819

[11] GIM, Sin. pev. 99.

[12] M. A. Ilin, “'Stone Chronicles' of Muscovy”, Moscow, 1966.

[13] A. B. Konotop, "Composition 'The Way to Heavenly Jerusalem' on the icon "Last Judgment" from the National Museum of Sweden (historiographic problems)": thesis, Moscow, 2007.

[14] N. P. Parfentiev, "On Activity of Fyodor Krestjanin - the Master of Musical-Written Art of the XVI -beginning XVII Centuries", Journal of Siberian Federal Universityб Humanities \& Social Sciences, vol. 2 (3), 2009, pp. 402-413.

[15] N. P. Parfentiev, "On work of the Trinity-Sergius monastery masters in Old Russian music art (through creativity of Login Shishelov)", The South Urals State University Reporter, the Social and Human Sciences series, vol. 1, 2013, pp. 92-103.

[16] M. Perrie, "Moscow in 1666: New Jerusalem, Third Rome, Third Apostasy", Quaestio Rossica journal, vol. 3, Yekaterinburg, 2014, pp.75-85.

[17] O.I. Podobedova, "Moscow painting school under Ivan IV”, Moscow, 1972.

[18] N. V. Ramazanova, "Muscovia in the ecclesiastical singing art of the XVI-XVII centuries", St. Petersburg, 2004.

[19] RGADA (Russian State Archive of Ancient Acts, Moscow), f. 188, d. 1585 .

[20] RGB (Russian State Library), Moscow, f. 228, d. 35.

[21] RGB, f. 304, d. 414.

[22] RGB, f. 304, d. 429.

[23] RGB, f. 379, d. 14.

[24] RNB (Russian National Library), St. Petersburg, Gruzd. 52.

[25] RNB, Kir. Bel. 639/896. 
[26] RNB, Kir. Bel. 657/914.

[27] RNB, Kir. Bel. 593/850.

[28] RNB, Kir. Bel. 707/964.

[29] RNB, O.I.403.

[30] RNB, Q.I.422.

[31] RNB, Q.I.1101.

[32] T. E. Samoilova, "The theme of chosen people in mural decoration of the Archangel Michael Cathedral", The Bible in culture and arts, Moscow, 1996, pp. 124-136.

[33] V. L. Snegirev, "The architectural monument St. Basil's Cathedral", Moscow, 1953

[34] I. M. Sokolova, "Monomakh's Throne. The tsar's place in the Dormition Cathedral of the Moscow Kremlin", Moscow, 2001.

[35] A. S. Usachev, "About the genesis of the idea of the Third Rome in Russia in the XVI century", St.Tikhon's Orthodox University Review. Series 2: History of the Russian Orthodox Church, vol. 3 (64), 2015, pp. 9-17. 